\title{
POINT: HOW FAMILY INVOLVEMENT INFLUENCES ORGANIZATIONAL CHANGE
}

\author{
Prof Josip Kotlar \\ Associate Professor of Strategy and Family Business \\ School of Management, Politecnico di Milano \\ Via R. Lambruschini 4/B, 20156 Milano (Italy) \\ Tel. +39 022399 9594, josip.kotlar@polimi.it \\ James J. Chrisman \\ Professor of Management \\ Department of Management and Information Systems \\ Mississippi State University \\ Mississippi State, MS 39762-9581 USA \\ Tel.+1 662-325-1991, jchrisman@cobilan.msstate.edu \\ and \\ Centre of Entrepreneurship and Family Enterprise \\ University of Alberta
}

Article accepted for publication in Journal of Change Management

Please cite as:

Kotlar, J., \& Chrisman, J. J. (2019). Point: How family involvement influences organizational change. Journal of Change Management, 19(1), 26-36. 


\title{
POINT: HOW FAMILY INVOLVEMENT INFLUENCES ORGANIZATIONAL CHANGE
}

\begin{abstract}
Family firms tend to exhibit substantial differences in their goals, governance, and resources in comparison to those of non-family firms. In this article, we briefly discuss these differences and their implications for organizational change and change management. We then summarize key findings in the literature pertaining to innovation and succession, two topics that have been extensively investigated and are closely allied to the topics of change and change management in family firms.
\end{abstract}

\section{INTRODUCTION}

Family involvement in ownership and management is a common feature of most business organizations worldwide (Astrachan \& Shanker, 2003; Chua, Chrisman, \& Sharma, 1999). Family firms are prevalent in many countries and industries, including one-third of the Fortune 500 and Standard and Poor's 500 (Shleifer \& Vishny, 1986), about half of publicly traded companies in Western Europe (Faccio \& Lang, 2002), and the great majority of publicly-traded firms in emerging economies (La Porta, Lopez-de-Silanes, Shleifer, \& Vishny, 1999). Prior research suggests that family involvement in business gives rise to a difficult trade-off between the continuity arising from shared family and firm history, values and traditions, and the need for organizational and strategic change arising with increasingly dynamic competitive environments (Chrisman \& Patel, 2012; Dyer, 1988; Handler \& Kram, 1988; Miller, Steier, \& Le Breton-Miller, 2003). If change is forgone in the name of continuity, family firms expose themselves to inertia and stagnation (Morck \& Yeung, 2004). If continuity is sacrificed to make way for change, however, family firms' distinctive sources of competitive advantage based on identity, social capital, reputation, and tacit knowledge could be lost (Habbershon \& Williams, 1999). Due to the difficult trade-offs between continuity and change, change management can be especially challenging for family firms but nonetheless vital for their long-term survival and prosperity. In this article, we discuss the 
influence of family involvement on organizational and strategic change. We do so by providing a foundation for defining family firms, understanding the main drivers of their distinctiveness in relation to change and change management, and outline opportunities for future research at the intersection of change management and family business research.

\section{CHANGE MANAGEMENT IN FAMILY FIRMS: AN OVERVIEW}

We define family firms according to a family's ownership and control of a firm and its vision for how the firm will benefit the family, potentially across generations (Bennedsen, Perez-Gonzalez, \& Wolfenzon. 2010; Chua et al., 1999). Family involvement is thought to influence the firm's goals, governance structure, and resources (Chrisman, Fang, Kotlar, \& De Massis, 2015; Chua, Chrisman, Steier, \& Rau, 2012), which in turn, can have major implications for change management in family firms.

First, family members pursue an array of economic goals as well as "particularistic" family-centered non-economic goals, which are more or less unique to family firms (Carney, 2005; Chrisman, Chua, Pearson, \& Barnett, 2012; Kotlar \& De Massis, 2013). Thus, in general the goal sets of family firms will be larger than those of non-family firms. Familycentered goals focus on the fulfillment of the family's social and affective needs through involvement in the firm. These include the ability to exercise authority, act altruistically toward family members, fulfill desires for belonging, affect and intimacy, and perpetuate the family's identity, values, and dynasty (Berrone, Cruz, \& Gomez-Mejia, 2012). These noneconomic goals create socioemotional wealth (SEW) for the family (Gómez-Mejía, Haynes, Núñez-Nickel, Jacobson, \& Moyano-Fuentes, 2007). ${ }^{1}$ They can either align or conflict with the financial goals of the firm (Chua, Chrisman, \& De Massis, 2015; Kotlar \& De Massis,

\footnotetext{
${ }^{1}$ The achievement of family-centered non-economic goals influence the family's stock of socioemotional wealth embedded in a firm just as the achievement of financial goals influences the financial wealth of a firm. Owing to their close relationship, we use the terms family-centered non-economic goals, family-centered goals, non-economic goals, and socioemotional wealth interchangeably through this article except if explicitly indicated otherwise.
} 
2013; Zellweger \& Nason, 2008), leading to a wider range of strategic decisions and outcomes in family firms than in non-family firms. Scholars using the behavioral agency model derivative of prospect theory (Wiseman \& Gómez-Mejía, 1998) suggest that family firm decisions are primarily driven by an aversion to the loss of SEW; in some cases even to the extent of sacrificing opportunities for financial gain when this helps minimize potential socioemotional losses (Gómez-Mejía et al., 2007).

However, existing research does not yet provide a definite explanation of whether family firms' non-economic goals facilitate or prevent organizational change. Some studies suggest that the emphasis on family-centered goals inhibits strategic change by leading to lower levels of diversification (e.g., Gómez-Mejía, Makri, \& Larraza-Kintana, 2010), mergers and acquisitions (e.g., Miller, Le Breton Miller, \& Lester, 2010) and R\&D investments (e.g., Chrisman \& Patel, 2012; Kotlar, Fang, De Massis, \& Frattini, 2014). However, others have shown that when family firms face a survival threat, they tend to reverse, at least temporarily, their preference for family-centered goals and engage in risky change designed to increase performance (Chrisman \& Patel, 2012; Gomez-Mejia et al., 2013; Sirmon, Arregle, Hitt, \& Webb, 2008). Family firms may also reverse their priorities with respect to SEW when such reversals are seen to maximize their utility (Vardaman \& Gondo, 2014).

Second, family involvement in ownership and management shapes a firm's governance structure by increasing the family members' power and discretion to follow idiosyncratic strategies that maximize the achievement of economic and family-centered noneconomic goals. The voting rights deriving from ownership and the active involvement in top management grant family members substantial authority over decision-making and isolate them from the interference of other stakeholders (Carney, 2005). In other words, family firm governance is characterized by "personalism" in that firm behavior closely reflects the will of 
family members. Family firm governance is characterized by benevolent contacts for family managers (Cruz, Gómez-Mejia, \& Becerra, 2010; Gómez-Mejía, Larraza-Kintana, \& Makri, 2003) and less formalized management practices (Carney, 2005). As such, it entails lower procedural rigor, making decisions in family firms sometimes less predictable and more capricious but also potentially more responsive and entrepreneurial. This governance setting can have important yet largely uninvestigated consequences for strategic and organizational change. Some scholars argue that the governance structures of family firms facilitate change because the largely unfettered discretion of family leaders allows them to effectively overcome inertia and take bold decisions leading to significant changes (e.g., Zahra, 2005). However, other scholars contend that this may not be the case because the concentration of power in family firm governance and a tendency to be loss averse with respect to SEW are more likely to lead to risk-averse strategies that preserve the status-quo (e.g., Morck, Stangeland, \& Yeung, 1998; Naldi, Nordqvist, Sjöberg, \& Wiklund, 2007).

Finally, the distinctive behavior of family firms also stems from unique resources embedded in the human and social capital created through interactions between family and business systems (Habbershon \& Williams, 1999; Habbershon, Williams, \& MacMillan, 2003; Sirmon \& Hitt, 2003). For example, informal communication channels and family norms can contribute to family firms' social capital in the form of bonding ties within the firm and bridging ties with external stakeholders (Arregle, Hitt, Sirmon, \& Very, 2007; Pearson, Carr, \& Shaw, 2008). However, the bifurcated and biased treatment of family and non-family employees in favor of the former can limit the quantity and quality of human resources in the firm (Chrisman, Memili, \& Misra, 2014; Verbeke \& Kano, 2012). Similarly, family firms' emphasis on parsimony (Carney, 2005) can lead family firms to make efficient and farsighted decisions regarding the investment and deployment of organizational resources (Zellweger, 2007). At the same time, the conflicting demands of family and business systems 
can sometimes lead to self-control issues and sub-optimal resource allocation decisions (De Massis, Kotlar, Mazzola, Minola, \& Sciascia, 2016; Schulze, Lubatkin, Dino, \& Buchholtz, 2001).

Family involvement in business is thought to promote access to some resources such as tacit knowledge, social capital, and reputation, and preclude access to other resources such professional managers, technical assets, and external financing (Carney, 2005; Gedajlovic \& Carney, 2010). As such, family involvement can provide unique stocks of resources that makes change management easier (Chrisman, Chua, \& Zahra, 2003; Habbershon \& Williams, 1999; Habbershon et al., 2003; Sirmon \& Hitt, 2003), or can create rigidities that prevent the ability to adjust the flows of resources needed to build the new resource stocks required for changing environmental circumstances (Sharma, 2008; Sirmon \& Hitt, 2003).

Taken together, the insights from prior research suggest that the relationship between family involvement and change is complex and possibly nonlinear. For example, prior research has shown that extremely high levels of family involvement can produce faultlines (Minichilli, Corbetta, \& MacMillan, 2010) that prevent non-family managers and employees from expressing new ideas and challenging the status quo (Patel \& Cooper, 2014). As such, intermediate levels of family involvement may be more conductive to change. Moreover, family firm goals, governance, and resources could have conflicting influences on change such as when family-centered non-economic goals make change seem less attractive even though the governance systems and resource configurations are available to facilitate effective change by allowing rapid decision-making and the transfer of tacit knowledge. Thus, given the potential for inconsistent relationships between their goals, governance, and resources, family firms may differ from non-family firms in terms of their willingness and ability to change, as well as the different types of change they embrace. 
As mentioned above, very few studies have directly addressed the trade-offs between continuity and organizational change in family firms and the differences in change management between family and non-family firms. Yet, research about specific behaviors and decisions does exist. In the remainder of this article, we focus on two major streams in family business research that have been the subject of substantial scholarly debate and empirical research - namely, innovation and succession in family business - both of which are intimately related to change and change management. By summarizing key findings on these topics, we hope to provide initial inputs for future theoretical and empirical research aimed at understanding change in family firms.

\section{INNOVATION AND CHANGE IN FAMILY FIRMS}

A growing body of research has been concerned with understanding the impact of family involvement on activities through which a firm conceives, designs, manufactures, and introduces new products, technologies, systems, or techniques (De Massis, Frattini, \& Lichtenthaler, 2013). Innovation and organizational change are closely interlinked. For example, Mezias and Glynn (1993) define innovation as "nonroutine, significant, and discontinuous organizational change" (p. 78). Accordingly, prior studies have shown that innovation, especially radical or discontinuous innovation is conducive to changes in existing organizational competencies (Mezias \& Glynn, 1993) and cognitions (Anderson \& Tushman, 1990). Therefore, research on family firm innovation can provide valuable insights about family firms' willingness and ability to engage in strategic and organizational change.

Family business scholars argue that family firms are generally reluctant to invest in $\mathrm{R} \& \mathrm{D}$ in order to preserve their family-centric governance structures, pursue their noneconomic goals, and protect their distinctive resources (Block, 2012; Chrisman \& Patel, 2012). Family firms often have limited internal funds to support R\&D investments; hence, they must increase their debt or external equity financing in order to engage in innovation. 
However, these are not always attractive options since they would dilute the family's control over the firm. R\&D investments involve planning, hiring external professionals, and disclosing private information to non-family managers, which could further reduce the power of family managers. Owing to technological and market uncertainty, R\&D investments involve a substantial amount of risk . Because risk, particularly the risk of bankruptcy, would affect both financial wealth and SEW, scholars believe that family firms have a heightened incentive to minimize R\&D investments (e.g., Chrisman \& Patel, 2012). For these reasons, family firms appear to have strong motivations to refrain from risky strategic investments in innovation. Combined with the idea that innovation and change are inextricably linked (e.g., Mezias \& Glynn, 1993), we may expect that family firms' governance structures, distinctive resources, and particularly, their emphasis on non-economic goals lead to a lower willingness to engage in organizational change.

Nonetheless, existing empirical studies suggest that lower R\&D investments do not necessarily result in lower innovation activity or outputs in family firms. In fact, prior research has shown that even if family firms do generally make lower R\&D investments, they display preference reversals and invest heavily in innovation when their financial performance aspirations are not being met by their current strategy (Chrisman \& Patel, 2012). Moreover, family firms engage in different types of innovation than non-family firms depending on the context: they prefer exploitative R\&D investments that focus on leveraging and incrementally improving existing services and products when performance is satisfactory, but shift their emphasis on explorative R\&D investments in the wake of negative performance feedback (Patel \& Chrisman, 2014). Furthermore, given their governance structures, which promote efficiency and the discretion to make unrestricted decisions, family firms appear to invest more in process innovations than non-family firms do (Broekaert, Andries, \& Debackere, 2016). 
Family firms seem to have different preferences when it comes to acquiring external knowledge (Kotlar, De Massis, Frattini, Bianchi, \& Fang, 2013) or adopting discontinuous innovations developed by others (König, Kammerlander, \& Enders, 2013). To circumvent the barriers dictated by their goals and governance structures, while economizing on their unique stock of resources embedded in the firm-specific tacit knowledge of family members, family firms may use different management processes (Chrisman, Chua, De Massis, Minola, \&Vismara, 2016) and organize innovation activities differently than non-family firms (De Massis, Kotlar, Frattini, Chrisman, \& Nordqvist, 2016). For reasons such as these, family firms may be able to achieve greater efficiency in innovation even though they usually invest fewer resources (Block, 2012; Duran, Kammerlander, van Essen, \& Zellweger, 2015).

The above discussion suggests that family firms are not necessarily averse to organizational change, but may simply engage in different types of change that are more consistent with their goals, governance, and resources. In fact, family firms may be better equipped to make change happen when it is needed the most. As noted above, family firms are prone to change their risk appetite and their innovation strategies when their performance is declining (Chrisman \& Patel, 2012; Gómez-Mejía et al., 2010; Patel \& Chrisman, 2014) or when they face threats from their competitors (Sirmon et al., 2008). Similarly, family firms tend to change their priorities and embrace greater change when the family faces the risk of losing control over decision-making (Kotlar, De Massis, Fang, \& Frattini, 2014). I

$\mathrm{n}$ sum, existing research on innovation in family firms provides theoretical arguments and empirical evidence for expecting that family involvement effects organizational change. However, future research examining how family involvement, along with family firms' goals, governance, and resources, drives organizational change is needed. As just one example, how conflicts are resolved among family owners or between family and non-family managers with regard to the optimal types or magnitude of change the firm requires would be useful. 


\section{MANAGEMENT SUCCESSION AND CHANGE IN FAMILY FIRMS}

The second area that has received considerable research interest in the family business literature, and holds substantial implications for understanding the impact of family involvement on organizational change, is management succession (e.g., Daspit, Holt, Chrisman, \& Long, 2016). Intra-family succession intention is a defining characteristic of family firms (Chua et al., 1999) and is widely recognized as one of the major challenges for their survival and long-term success (Chua, Chrisman, \& Sharma, 2003; Le Breton-Miller, Miller, \& Steier, 2004). Management succession in general is often a disruptive process for firms in that it entails substantial changes that could either improve or undermine the future performance of the firm (e.g., Grusky, 1960). Prior research has found that "internal" succession, or when the new CEO is selected from within the firm, is generally less disruptive and more successful in terms of future firm performance than successions involving an external CEO (Shen \& Cannella, 2002; Zhang \& Rajagopalan, 2004). Nonetheless, the family business literature emphasizes a number of challenges associated with the transfer of knowledge, power, and control from the current generation of family leaders to the next one (Cabrera-Suárez, De Saa-Perez, \& García-Almeida, 2001; Handler, 1994). Miller et al. (2003) argue that intra-family succession presents family firms with strong tensions between continuity and change, often leading to dysfunctional patterns such as the family firm remaining too strongly attached to past strategies and ways of organizing, completely rejecting them for the sake of change, or incongruently blending the two, leading to wavering and inconsistent behaviors. On the other hand, De Massis, Chua and Chrisman (2008) identify a number of factors, including personal, relational, financial, and situational factors that may prevent intra-family succession from ever taking place. For these reasons, intra-family succession can not only be an agonizing experience for family firms, but one for which prior research has reported high rates of failure (e.g., Ward, 2004). 
The vast literature on family business succession suggests that family firm goals, governance, and resources can play important roles in determining whether and how the succession process leads to strategic and organizational changes in family firms. First, the governance structures of family firms are based on informal decision-making processes that allow family members to preserve power and authority within the family (Carney, 2005; Chrisman et al., 2014; Daily \& Dollinger, 1992). As such, family firms tend to avoid professionalization and are reluctant to hire and delegate authority to nonfamily managers. Family firms' strong preference for intra-family succession, combined with their lower willingness and ability to professionalize the governance of the firm through the appointment of nonfamily managers may preclude major strategic and organizational change during the succession process.

Second, the quality and quantity of family members able and willing to manage the firm in an effective manner remains naturally limited (Verbeke \& Kano, 2012). A dominant theme in the literature is that a firm's performance will decline when it is managed by successors rather than founders (e.g., Bennedsen, Nielsen, Perez-Gonzalez, \& Wolfenzon, 2007). Consequently, intra-family succession can give rise to negative outcomes when the choice of successor is based on altruistic considerations rather than merit, or the successor focuses on maximizing private benefits rather than the performance of the firm or the wellbeing of the family. Thus, family firm governance and the pursuit of non-economic goals can lead to the entrenchment of incompetent or opportunistic family CEOs (Cruz et al., 2010; Gómez-Mejía et al., 2003; Schulze et al., 2001). If family managers are shielded from the negative consequences of their work, they may be encouraged to initiate ill-advised change or forego needed changes that are perhaps not within their comfort zones.

Finally, the management of change during intra-family succession involves changes to the role of the incumbents, who often remain involved in the firm. Even when they do not, 
the shadow of founding or outgoing leaders can still carry considerable influence in the firm long after their official departure as CEO (Davis \& Harveston, 1999). Indeed, prior to and following an intra-family succession, the previous leaders - especially founders - may experience substantial difficulties in letting go of the firm (Rouse, 2016). The next generation CEO runs the risk of remaining highly dependent on the strategies and organizational arrangements used in the past (Sonfield \& Lussier, 2004). As such, successors may find their options for change are limited. Conversely, resentments for an interfering ex-family CEO might triggers change initiatives that are purely rebellious rather than strategic (Miller et al., 2003). Not surprisingly then, the types, extent, and effectiveness of change in family firms, especially during the periods immediately prior to, during, and following a succession event primarily depend upon the interactions and abilities of the outgoing incumbent, incoming successor, and the management team, which often includes members from outside the family.

\section{CONCLUSION}

In this article, we have briefly outlined some of the implications of family involvement in business on organizational change and change management. Although the literature provides very few direct insights on these relationships, research on family business innovation and succession in family firms suggests that the "family" variable is likely to be an important driver of change. Yet, this research also point to conflicting theoretical predictions and empirical evidence about the influence of family involvement on change, with some scholars arguing that family involvement creates particularly strong barriers for change and others suggesting that family firms can successfully embrace change and even have superior capabilities in implementing change. Our discussion has focused on general tendencies associated with family involvement in the firm. Our conclusion is that family involvement leads to change behaviors that are different both in their types and amounts in comparison to those of non-family firms. However, while the general differences between 
family and non-family firms in relation to innovation and succession can provide some initial hints about the relationship between family involvement and change, more work on the wide variety of changes to the strategies, structures, systems, and processes of family firms is needed (cf., Chrisman et al., 2016).

Existing theory needs to be further elaborated and developed in order to provide more nuanced predictions about the influence of family involvement on change as well as the role of critical moderators such as firm size, age, level of family and non-family involvement, etc. An analysis of the goals, governance, and resources of family firms can assist future research in this direction. This article only begins to address the complex issues associated with change in family firms, but we hope it offers some initial insights to researchers who wish to investigate how change and change management differs between family and non-family firms. 


\section{REFERENCES}

Anderson, P. \& Tushman, M. L. 1990. Technological discontinuities and dominant designs:

A cyclical model of technological change. Administrative science quarterly, 604-633.

Arregle, J. L., Hitt, M. A., Sirmon, D. G., \& Very, P. 2007. The development of organizational social capital: attributes of family firms. Journal of Management Studies, 44(1), 73-106.

Astrachan, J. H. \& Shanker, M. C. 2003. Family businesses' contribution to the US economy: A closer look. Family Business Review, 16(3), 211-219.

Bennedsen, M., Nielsen, K.M., Perez-Gonzalez, F., \& Wolfenzon, D. 2007. Inside the family

firm: The role of families in succession decisions and performance. Quarterly Journal of

Economics, 122(2), 647-691.

Bennedsen, M., Pérez-González, F., \& Wolfenzon, D. 2010. The governance of family firms. In Baker, K.H. \& Anderson, R. (Eds.), Corporate governance: A synthesis of theory, research, and practice (pp. 371-390). Hoboken, NJ: Wiley.

Berrone, P., Cruz, C., \& Gomez-Mejia, L. R. 2012. Socioemotional Wealth in Family Firms: Theoretical Dimensions, Assessment Approaches, and Agenda for Future Research. Family Business Review, 25(3), 258-279.

Block, J. H. 2012. R\&D investments in family and founder firms: An agency perspective. Journal of Business Venturing, 27(2), 248-265.

Broekaert, W., Andries, P., \& Debackere, K. 2016. Looking beyond R\&D as enabler of innovation: Family firms' organizational flexibility advantage. Small Business Economics, 47(3), 771-785.

Cabrera-Suárez, K., De Saa-Perez, P., \& García-Almeida, D. 2001. The succession process from a resource-and knowledge-based view of the family firm. Family Business Review, 14(1), 37-46.

Carney, M. 2005. Corporate governance and competitive advantage in family-controlled firms. Entrepreneurship Theory and Practice, 29(3), 249-265.

Chrisman, J. J., Chua, J. H., \& Zahra, S. A. 2003. Creating wealth in family firms through managing resources: Comments and extensions. Entrepreneurship Theory and Practice, 27(4), 359-365.

Chrisman, J. J., Chua, J. H., Pearson, A. W., \& Barnett, T. 2012. Family Involvement, Family Influence, and Family Centered Non Economic Goals in Small Firms. Entrepreneurship Theory and Practice, 36(2), 267-293.

Chrisman, J.J., Chua, J.H., De Massis, A., Minola, T., \&Vismara, S. 2016. Management processes and strategy execution in family firms: From "what" to "how". Small Business Economics, 47(3), 719-734.

Chrisman, J. J. \& Patel, P. J. 2012. Variations in R\&D investments of family and non-family firms: Behavioral agency and myopic loss aversion perspectives. Academy of Management Journal, 55(4), 976-997.

Chrisman, J. J., Memili, E., \& Misra, K. 2014. Nonfamily managers, family firms, and the winner's curse: The influence of noneconomic goals and bounded rationality.

Entrepreneurship Theory and Practice, 38(5), 1103-1127. 
Chrisman, J. J., Fang, H., Kotlar, J., \& De Massis, A. 2015. A note on family influence and the adoption of discontinuous technologies in family firms. Journal of Product Innovation Management, 32(3), 384-388.

Chua, J. H., Chrisman, J. J., \& Sharma, P. 1999. Defining the family business by behavior. Entrepreneurship Theory and Practice, 23(4), 19-39.

Chua, J. H., Chrisman, J. J., \& Sharma, P. 2003. Succession and nonsuccession concerns of family firms and agency relationship with nonfamily managers. Family Business Review, 16(2), 89-107.

Chua, J. H., Chrisman, J. J., Steier, L. P., \& Rau, S. B. 2012. Sources of Heterogeneity in Family Firms: An Introduction. Entrepreneurship Theory and Practice, 36(6), 1103 1113.

Chua, J. H., Chrisman, J. J., \& De Massis, A. 2015. A closer look at socioemotional wealth: its flows, stocks, and prospects for moving forward. Entrepreneurship Theory and Practice, 39(2), 173-182.

Cruz, C. C., Gómez-Mejia, L. R., \& Becerra, M. 2010. Perceptions of benevolence and the design of agency contracts: CEO-TMT relationships in family firms. The Academy of Management Journal, 53(1), 69-89.

Daily, C. M. \& Dollinger, M. J. 1992. An empirical examination of ownership structure in family and professionally managed firms. Family Business Review, 5(2), 117-136.

Daspit, J., Holt, D., Chrisman, J.J., \& Long, R. 2016. Examining family firm succession from a social exchange perspective: A multi-phase, multi-stakeholder review. Family Business Review, 29(1), 44-64.

Davis, P. S. \& Harveston, P. D. 1999. In the founder's shadow: Conflict in the family firm. Family Business Review, 12(4), 311-323.

De Massis, A., Chua, J. H., \& Chrisman, J. J. 2008. Factors Preventing Intra Family Succession. Family Business Review, 21(2), 183-199.

De Massis, A., Frattini, F., \& Lichtenthaler, U. 2013. Research on Technological Innovation in Family Firms: Present Debates and Future Directions. Family Business Review, 26(1), 10-31.

De Massis, A., Kotlar, J., Frattini, F., Chrisman, J. J., \& Nordqvist, M. 2016. Family Governance at Work: Organizing for New Product Development in Family SMEs. Family Business Review, 29(2), 189-213.

De Massis, V. A., Kotlar, J., Mazzola, P., Minola, T., \& Sciascia, S. 2016. Conflicting selves: family owners' multiple goals and self-control agency problems in private firms. Entrepreneurship Theory and Practice, DOI: 10.1111/etap.12257

Duran, P., Kammerlander, N., van Essen, M., \& Zellweger, T. 2015. Doing more with less: Innovation input and output in family firms. Academy of Management Journal, 59(4), 1224-1264.

Dyer, W. G. 1988. Culture and continuity in family firms. Family Business Review, 1(1), 37 50.

Faccio, M. \& Lang, L. H. P. 2002. The ultimate ownership of Western European corporations. Journal of Financial Economics, 65(3), 365-395. 
Gedajlovic, E. \& Carney, M. 2010. Markets, Hierarchies, and Families: Toward a Transaction Cost Theory of the Family Firm. Entrepreneurship Theory and Practice, 34(6), 1145-1172.

Gómez-Mejía, L. R., Larraza-Kintana, M., \& Makri, M. 2003. The determinants of executive compensation in family-controlled public corporations. The Academy of Management Journal, 46(2), 226-237.

Gómez-Mejía, L. R., Haynes, K. T., Núñez-Nickel, M., Jacobson, K. J. L., \& MoyanoFuentes, J. 2007. Socioemotional wealth and business risks in family-controlled firms: Evidence from Spanish olive oil mills. Administrative Science Quarterly, 52(1), 106137.

Gómez-Mejía, L. R., Makri, M., \& Larraza-Kintana, M. 2010. Diversification decisions in family-controlled firms. Journal of Management Studies, 47(2), 223-252.

Grusky, O. 1960. Administrative succession in formal organizations. Social Forces, 39(2), 105-115.

Habbershon, T. G. \& Williams, M. 1999. A Resource-Based Framework for Assessing the Strategic Advantages of Family Firms. Family Business Review, 12(1), 1-25.

Habbershon, T. G., Williams, M., \& MacMillan, I. C. 2003. A unified systems perspective of family firm performance. Journal of Business Venturing, 18(4), 451-465.

Handler, W. C. \& Kram, K. E. 1988. Succession in family firms: The problem of resistance. Family Business Review, 1(4), 361-381.

Handler, W. C. 1994. Succession in family business: A review of the research. Family business review, 7(2), 133-157.

König, A., Kammerlander, N., \& Enders, A. 2013. The Family Innovator's Dilemma: How Family Influence Affects the Adoption of Discontinuous Technologies by Incumbent Firms. Academy of Management Review, 38(3), 418-441.

Kotlar, J. \& De Massis, A. 2013. Goal setting in family firms: Goal diversity, social interactions, and collective commitment to family-centered goals. Entrepreneurship Theory and Practice, 37(6), 1263-1288.

Kotlar, J., De Massis, A., Frattini, F., Bianchi, M., \& Fang, H. 2013. Technology Acquisition in Family and Non-Family Firms: A Longitudinal Analysis of Spanish Manufacturing Firms. Journal of Product Innovation Management, 30(6), 1073-1088.

Kotlar, J., De Massis, A., Fang, H. C., \& Frattini, F. 2014. Strategic reference points in family firms. Small Business Economics, 43(3), 597-619.

Kotlar, J., Fang, H., De Massis, A., \& Frattini, F. 2014. Profitability goals, control goals, and the R\&D investment decisions of family and non-family firms. Journal of Product Innovation Management, 31(6), 1128-1145.

La Porta, R., Lopez-de-Silanes, F., Shleifer, A., \& Vishny, R. 1999. Corporate ownership around the world. Journal of Finance, 54(2), 471-517.

Le Breton-Miller, I. L., Miller, D., \& Steier, L. P. 2004. Toward an integrative model of effective FOB succession. Entrepreneurship Theory and Practice, 28(4), 305-328.

Mezias, S. J. \& Glynn, M. A. 1993. The three faces of corporate renewal: Institution, revolution, and evolution. Strategic Management Journal, 14(2), 77-101. 
Miller, D., Steier, L., \& Le Breton-Miller, I. 2003. Lost in time: intergenerational succession, change, and failure in family business. Journal of Business Venturing, 18(4), 513531.

Miller, D., Le Breton Miller, I., \& Lester, R. H. 2010. Family ownership and acquisition behavior in publicly traded companies. Strategic Management Journal, 31(2), 201223.

Minichilli, A., Corbetta, G., \& MacMillan, I. C. 2010. Top Management Teams in FamilyControlled Companies:'Familiness','Faultlines', and Their Impact on Financial Performance. Journal of Management Studies, 47(2), 205-222.

Morck, R., Stangeland, D. A., \& Yeung, B. 1998. Inherited wealth, corporate control and economic growth: The Canadian disease. In R. Morck (Ed.), Concentrated Corporate Ownership, 319-369. Chicago: University of Chicago Press.

Morck, R. \& Yeung, B. 2004. Family control and the rent seeking society. Entrepreneurship Theory and Practice, 28(4), 391-409.

Naldi, L., Nordqvist, M., Sjöberg, K., \& Wiklund, J. 2007. Entrepreneurial orientation, risk taking, and performance in family firms. Family Business Review, 20(1), 33-47.

Patel, P. \& Cooper, D. 2014. Structural power equality between family and non-family TMT members and the performance of family firms. Academy of Management Journal, 57(6), 1624-1649.

Patel, P. C. \& Chrisman, J. J. 2014. Risk abatement as a strategy for R\&D investments in family firms. Strategic Management Journal, 35(4), 617-627.

Pearson, A. W., Carr, J. C., \& Shaw, J. C. 2008. Toward a theory of familiness: A social capital perspective. Entrepreneurship Theory and Practice, 32(6), 949-969.

Rouse, E. D. 2016. Beginning's end: How founders psychologically disengage from their organizations. Academy of Management Journal, 59(5), 1605-1629.

Schulze, W. S., Lubatkin, M. H., Dino, R. N., \& Buchholtz, A. K. 2001. Agency relationships in family firms: Theory and evidence. Organization Science, 12(2), 99-116.

Sharma, P. 2008. Commentary: Familiness: Capital stocks and flows between family and business. Entrepreneurship Theory and Practice, 32(6), 971-977.

Shen, W. \& Cannella, A. A. 2002. Power dynamics within top management and their impacts on CEO dismissal followed by inside succession. Academy of Management Journal, 45(6), 1195-1206.

Shleifer, A. \& Vishny, R. W. 1986. Large shareholders and corporate control. The Journal of Political Economy, 94(3), 461-488.

Sirmon, D. G. \& Hitt, M. A. 2003. Managing resources: Linking unique resources, management, and wealth creation in family firms. Entrepreneurship Theory and Practice, 27(4), 339-358.

Sirmon, D. G., Arregle, J. L., Hitt, M. A., \& Webb, J. W. 2008. The role of family influence in firms' strategic responses to threat of imitation. Entrepreneurship Theory and Practice, 32(6), 979-998.

Sonfield, M. C. \& Lussier, R. N. 2004. First, Second, and Third Generation Family Firms: A Comparison. Family Business Review, 17(3), 189-202.

Vardaman, J.M. \& Gondo, M.B. 2014. Commentary: Socioemotional wealth conflict in family firms. Entrepreneurship Theory and Practice, 38(6), 1317-1322. 
Verbeke, A. \& Kano, L. 2012. The Transaction Cost Economics Theory of the Family Firm: Family-Based Human Asset Specificity and the Bifurcation Bias. Entrepreneurship Theory and Practice, 36(6), 1183-1205.

Ward, J. L. 2004. Perpetuating the family business: Palgrave Macmillan.

Wiseman, R. M. \& Gómez-Mejía, L. R. 1998. A behavioral agency model of managerial risk taking. The Academy of Management Review, 23(1), 133-153.

Zahra, S. A. 2005. Entrepreneurial risk taking in family firms. Family Business Review, 18(1), 23-40.

Zellweger, T. M. 2007. Time horizon, costs of equity capital, and generic investment strategies of firms. Family Business Review, 20(1), 1-15.

Zellweger, T. M. \& Nason, R. S. 2008. A stakeholder perspective on family firm performance. Family Business Review, 21(3), 203-216.

Zhang, Y. \& Rajagopalan, N. 2004. When the known devil is better than an unknown god: An empirical study of the antecedents and consequences of relay CEO successions. Academy of Management Journal, 47(4), 483-500. 